lars is known to be caused every year in this country by imported plant and tree pests. Whose concern should it be to take every possible measure to learn the nature of the pine-tree blister rust which threatens property of New York City to the extent of several millions of dollars? Would it not be a perfectly reasonable business proposition to expend annually 10 per cent. of the value of the trees on the Ashokan watershed in order to ascertain effective means for the control or eradication of a tree disease which may necessitate a replanting of the entire area?

Several million dollars worth of potatoes are consumed in greater New York every year; who should be more interested than the residents of this city in supporting botanical research that has for its object the eradication of potato diseases in Maine, whence a large percentage of our supply is derived?

By the scientific and educational opportunities which it can afford our citizens, by diffusing in this community, and from this community as a center, a knowledge and love of plants, by botanical investigations in the realms of pure and applied science, the Brooklyn Botanic Garden can yearly render to the city of New York a service whose value will be far in excess of any sum of money that will ever be necessary for its annual maintenance.

At the opening of the Pasteur Institute, in Paris, in 1888, the founder of the science of bacteriology, near the close of his address, spoke as follows, smarting as he always did, at the memory of the events of the Franco-Prussian war:

If science has no country, the scientist should have one, and ascribe to it the influence which his works may have in this world. If I might be allowed, Mr. President, to conclude by a philosophical remark inspired by your presence in this Home of Work, I should say that two contrary laws seem to be wrestling with each other nowadays; the one a law of blood and of death, ever imagining new means of destruction, and forcing nations to be constantly ready for the battlefield-the other, a law of peace, work and health, ever evolving new means of delivering man from the scourges which beset him.

These words seem written for the present occasion. Almost the entire civilized world is at war, but the ultimate triumph of freedom over tyranny, of civilization over vandalism, of right over wrong, may now be confidently predicted; peace, let us hope, is not far distant. In the realm of the intelleet there is perpetual conflict of light over darkness, right over wrong, knowledge over ignorance and superstition. But the. strongholds of ignorance and superstition, while perpetually yielding are eternally holding out. We shall never know it all, there will forever be ample opportunity for and need of scientific research-of the advancement and diffusion of knowledge. This is man's largest opportunity, the ultimate source of his greatest happiness.

C. Stuart Gager

BrookLyn Botanic Garden

\section{THE SCIENTIFIC WORK OF THE BUREAU OF FISHERIES}

AFTer most careful consideration of its responsibilities in the present national exigency, the Bureau of Fisheries has determined upon the following principles and plans for its immediate guidance:

1. The service of science to fishery work is of such great possible significance that it would be a serious error to abandon the pursuit of proper scientific investigations.

2. The exigency of the national food situation is such that every practicable and proper effort should be made to bring about a greater production of fish and a better utilization of the available supply.

3. The conflict between the two principles just mentioned is more apparent than real, as may appear from the following statementroft the bureau's plan.

as bobrsigs" esi

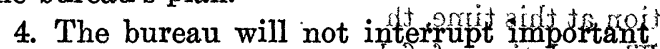
investigations which have been pursued for 
periods of years and which must be continued in order to gain the desired results.

5. As between new investigations which may be expected to yield returns after a long period of years and those which may be expected to produce results in time to serve the immediate needs of the country, preference will be given to the latter.

6. In the latter class are studies-biological, biochemical, physiological and technologicalrelating to the propagation and rearing of fish, the protection of fish, the utilization of fishery products, etc.

7. The bureau is not only utilizing its permanent scientific staff to the fullest extent, but is gladly availing itself of the valuable assistance offered by biologists, physiologists and chemists from various universities.

8. For the immediate present certain economies are being practised. This does not mean a policy of niggardliness; on the contrary, expenditures must in many respects be more liberal than hitherto. It does mean, however, the temporary curtailment or cessation of certain customary activities which can not be continued in a satisfactory manner during the immediate period of necessary readjustment.

More specifically the bureau's plans for scientific work in the near future may be stated as follows:

The marine laboratory at Beaufort, N. C., will not be opened for general investigations during the coming summer. The Woods Hole laboratory, while temporarily closed for general investigations, will have a small special staff for experimental work in the utilization of fishery products. The fish-culture experiment work of the Fairport, Iowa, laboratory bears so directly upon the immediate problems of food supply that the activities of the station will suffer no curtailment, but will be somewhat expanded. In the class of field investigations, some will be continued, some abandoned and some new studies undertaken.

Not as a complete catalogue of investigations provided for, but as illustrating the topics regarded as proper for the bureau's attention at this time, the following may be selected: The relation of fishes to mosquito extermina- tion and to public health; the habits and propagation of salmon in Pacific waters; the natural history, propagation and protection of the blue crab; problems of the oyster industry; experiments in curing fishes; the properties of the roe of certain fishes alleged to be toxic or distasteful; various other investigations relating to the utilization of fishery products; dragon-flies and damsel-flies in relation to the culture of fishes in ponds; aquatic plants in relation to the culture of fishes in ponds; parasites affecting fish culture in ponds, life-histories, and means of control; systematic relations, habits and migrations of salmonoid fishes in the Great Lakes; biological and physical conditions of fish life in enclosed waters; the protection of wood against marine borers; the utilization of marine algæ, and the relation of kelp harvesting to the fisheries.

\section{H. M. SMith, Commissioner of Fisheries}

WASHINGTON, D. C., June 18, 1917

\section{SCIENTIFIC EVENTS}

CONCERNING THE MANUFACTURE OF PHTHALIC ACID AND PHTHALIC ANHYDRIDE

THE Department of Agriculture announces that the color investigation laboratory of the Bureau of Chemistry, of this department, has perfected, on a laboratory scale, a new process for the manufacture of phthalic acid and phthalic anhydride. This process, as carried out in the laboratories, appears so promising that it is thought that some manufacturers of chemicals and dyestuffs in this country may be able to supply their demands for these compounds by this process, provided the process can be reproduced upon a technical scale so as to obtain results commensurate with the laboratory investigations.

With a view to helping the chemical industry of this country, the Department of Agriculture hereby announces that it is ready to assist manufacturers who wish to produce these compounds. The expenses of the technical installation and of the labor and materials necessary will of necessity be borne by the firm, individual, or corporation wishing to manufac- 